\title{
Pemetaan Potensi Desa Berbasis Asset Based Community Development di Desa Kotabatu, Pubian, Lampung Tengah
}

\author{
Yulianto, Teuku Fahmi, Selvi D. Meilinda, Dewi A. Hidayati, Astiwi Inayah \\ Fakultas Ilmu Sosial dan Ilmu Politik, Universitas Lampung \\ Korespondensi: yulianto@fisip.unila.ac.id
}

\begin{abstract}
The purpose of this community service activity was to increase the knowledge and experience of local communities at village potential mapping based on asset based community development in Kotabatu Village. The activities carried out are in the form of focus group discussion (FGD), training that accompanied by assistance in the context of mapping of village potential and increasing the institutional capacity of community groups, namely: Community Forestry Group and Tourism Awareness Group. The methods used in this activity included: the cognitive aspect enhancement stage, the mentoring and empowerment stage, and the advocacy stage. In particular, this community service activity has led to several objectives, including: building a commitment among village officials to focus on village development of the three potential Kotabatu Village has had, including (1) optimizing the potential of natural resources, (2) potential agricultural products, and (3) tourism potential.
\end{abstract}

Keywords: Mapping; exploration; village potential; community development

\begin{abstract}
Abstrak
Tujuan pelaksanaan kegiatan pengabdian ini ialah meningkatkan pengetahuan dan pengalaman masyarakat lokal dalam memetakan potensi desa berbasiskan asset based community development di Desa Kotabatu, Kec. Pubian, Kab. Lampung Tengah. Kegiatan yang dilakukan berbentuk forum group discussion (FGD), pelatihan, dan dibarengi dengan pendampingan dalam rangka pemetaan (eksplorasi) potensi desa, serta peningkatan kapasitas kelembagaan kelompok masyarakat, yakni Kelompok Hutan Kemasyarakatan-HKm dan Kelompok Sadar Wisata (Pokdarwis). Metode yang digunakan dalam kegiatan ini di antaranya adalah tahap peningkatan aspek kognitif, tahap pendampingan dan pemberdayaan, serta tahap advokasi. Secara khusus, kegiatan pengabdian ini telah mengarah pada beberapa capaian tujuan, di antaranya, yakni terbangunnya komitmen di antara aparatur desa untuk memfokuskan pengembangan desa pada tiga potensi yang dimiliki oleh Desa Kotabatu, di antaranya, yakni (1) optimalisasi potensi SDA, (2) potensi hasil bumi, dan (3) potensi pariwisata.
\end{abstract}

Kata kunci: pemetaan; eksplorasi; potensi desa; pemberdayaan masyarakat

\section{Pendahuluan}

Pada Januari 2020, Kementerian Pendidikan dan Kebudayaan (Kemendikbud) RI melakukan gebrakan dengan meluncurkan Proyek Membangun Desa (Kemendikbud. go.id, 31/01). Dalam hal ini, Kemendikbud akan merealisasikan "Proyek Membangun Desa" dengan berkolaborasi bersama pihak lainnya, yakni Kementerian Desa, Pembangunan Daerah Tertinggal dan Transmigrasi (Kemendes PDTT). Dari perspektif 
Kemdikbud, muara dari proyek tersebut di antaranya adalah menjadi sarana penguatan karakter mahasiswa yang merupakan perwujudan dari kebijakan Merdeka Belajar Kampus Merdeka (MBKM), khususnya program Membangun Desa (KKN Tematik). Sementara itu, dari Kemendes PDTT, proyek tersebut dapat memperkuat dan meningkatkan sumber daya manusia, utamanya di kawasan pedesaan (Kompas.com, 31/01). Kedua institusi tersebut mengikat komitmen "Proyek Membangun Desa" dengan membentuk Forum Perguruan Tinggi Desa (Fortides). Diharapkan, peran perguruan tinggi nantinya akan lebih mampu "membumikan" konsep operasional pembangunan SDM unggul dan mentransformasikan ekonomi kawasan perdesaan.

Sebagaimana diketahui bersama, Undang-Undang Nomor 6 Tahun 2014 tentang Desa (yang selanjutnya disebut UU Desa) merupakan landasan utama dari pembangunan kawasan perdesaan di Indonesia. Adanya UU Desa tersebut telah menjadi preferensi krusial dalam proses pembangunan di Indonesia. Dalam kerangka peraturan perundangundangan ini, desa ditempatkan sebagai posisi sentral dalam pembangunan guna meningkatkan kesejahteraan masyarakat (Yulianto, Diana et al., 2021). Implementasi Dana Desa (DD) sebagai amanat dari UU Desa terus didorong oleh pemerintah pusat dalam rangka

peningkatan partisipasi masyarakat desa dalam membangun wilayahnya. Hal ini terlihat dari jumlah alokasi program DD yang selalu meningkat pada tiap tahunnya. Lebih dari itu, Kemendesa PDTT juga telah menetapkan empat program prioritas yang mencakup dan didesain sebagai satu kesatuan yang saling menunjang guna terciptanya kemandirian desa. Keempat program tersebut ialah (1) pengembangan produk unggulan kawasan perdesaan (Prukades), (2) badan usaha milik desa (BUMDes), (3) embung desa, dan (4) sarana olah raga desa. Maksud dari program prioritas tersebut ialah desa, dengan segala ciri khas/keunikan yang dimilikinya, mampu menemu-kenali keunggulan lokal

Tabel 1. Sebaran Jumlah BUMDes dan Prukades di Provinsi Lampung, 2020

\begin{tabular}{|c|c|c|c|}
\hline No. & Kabupaten & Jumlah BUMDes & Jumlah Prukades \\
\hline 1 & Lampung Barat & 7 & - \\
\hline 2 & Lampung Selatan & 36 & - \\
\hline 3 & Lampung Tengah & 2 & 3 \\
\hline 4 & Lampung Timur & 242 & - \\
\hline 5 & Lampung Utara & 117 & 5 \\
\hline 6 & Mesuji & 2 & - \\
\hline 7 & Pesawaran & 3 & - \\
\hline 8 & Pesisir Barat & 3 & 6 \\
\hline 9 & Tanggamus & 5 & 4 \\
\hline 10 & Tulang Bawang & 4 & 23 \\
\hline 11 & T. Bawang Barat & 7 & \\
\hline 12 & Way Kanan & 482 & \\
\hline & Total & & \\
\hline
\end{tabular}

Sumber: Kompilasi data datin.kemendesa.go.id dan prukades.kemendesa.go.id 
yang ada di desa tersebut lalu mengeksplorasi dan memanfaatkannya hingga mampu mendatangkan kesejahteraan bagi masyarakatnya.

Berkaca dari data sekunder, jumlah BUMDes yang ada Provinsi Lampung terdapat sebanyak 482 (Datin Kemendesa, 2020), sedangkan untuk Prukades berkisar 23 saja (lihat Tabel 1). Perbandingan yang sangat timpang ini menunjukkan bahwa desa perlu difasilitasi untuk mendapatkan pendampingan dalam mengidentifikasi beragam produk unggulan lokal tersebut.

Mengacu pada Tabel $1 \mathrm{di}$ atas, terdapat dua kabupaten yang memiliki jumlah BUMDes terrendah yakni Kab. Lampung Tengah dan Kab. Pesawaran. Untuk konteks Kab. Pesawaran dapat dikesampingkan karena merupakan daerah otonomi baru (DOB) yang merupakan pecahan dari Kabupaten Lampung Selatan. Namun, untuk Kab. Lampung Tengah, sebagai salah satu kabupaten tertua di Provinsi Lampung, capaian jumlah BUMDes dan Prukades di atas haruslah mendapat perhatian khusus dari berbagai stakeholders. Mengingat potensi sumber daya melimpah yang dimiliki kabupaten dengan slogan "Beguwai Jejamo Wawai-bekerja sama dalam mewujudkan kepentingan masyarakat menuju kebaikan" ini, menarik untuk dilakukan kajian pemetaan dan pendampingan desa-desa yang ada di Kabupaten Lampung Tengah berbasiskan asset based community development, terlebih untuk di wilayah sekitar Kecamatan Pubian terkhusus Desa Kotabatu yang terdapat terdapat potensi wisata hutan ekowisata (Gambar 1).

Mengacu pada Indeks Desa Membangun (IDM) yang dirilis oleh Kemendesa PDTT (2020), Desa Kotabatu berada di kategori “Desa Berkembang”. Meskipun demikian, terdapat beberapa permasalahan yang terkait dengan optimalisasi sumber daya lokal yang dimiliki oleh desa tersebut. Hasil penelusuran melalui pemberitaan online ditemukan beragam potensi desa yang dimiliki oleh Kampung Kotabatu, salah satunya ialah Potensi Hutan Kemasyarakatan (HKm). Kelompok HKm yang ada di Desa Kotabatu fokus untuk membudidayakan kemiri sebagai komoditas unggulan mereka. Selain Kemiri, masyarakat Kotabatu juga terbiasa mengambil berbagai jenis hasil hutan, semisal madu dan rotan. Kendala terbesar yang dialami oleh kelompok HKm tersebut ialah harga yang anjlok ketika panen Kemiri berlangsung (Youtube.com, 17/2).

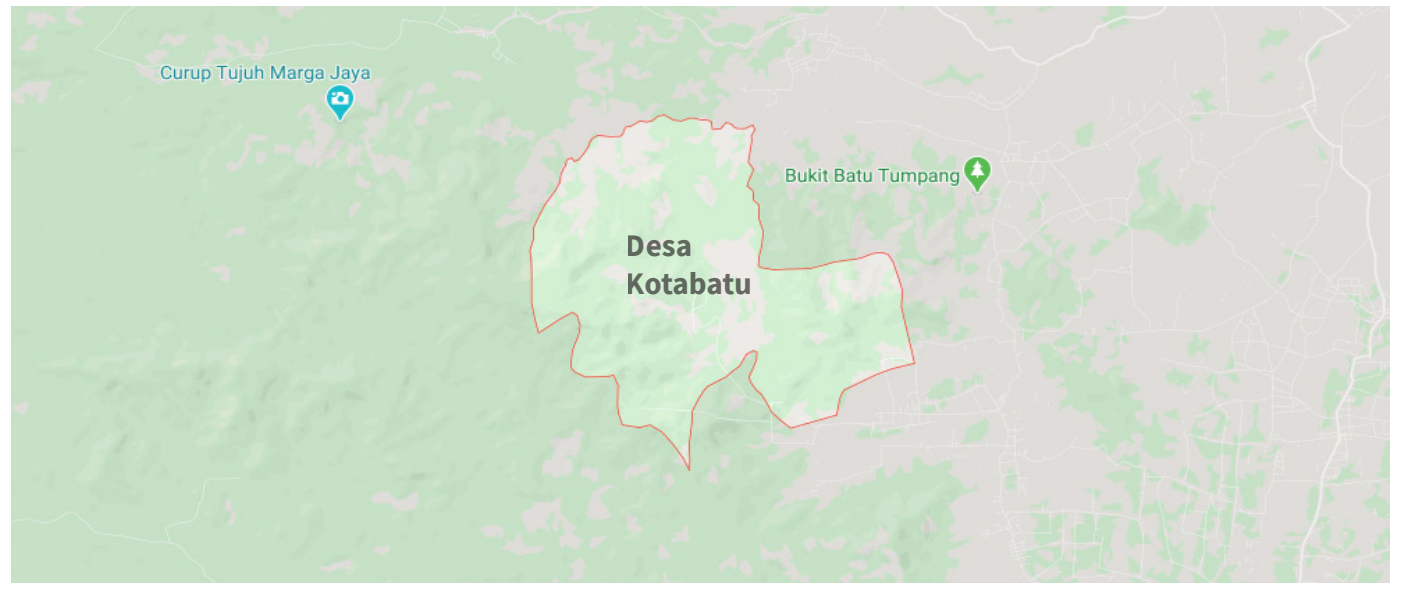

Gambar 1. Desa Kotabatu, Kec. Pubian, Kab. Lampung Tengah. Sumber: https://maps.google.co.id. 
Pada aspek lain, pengembangan destinasi wisata di Desa Kotabatu yang perlu perhatian dari berbagai pihak. Terdapat beberapa air terjun yang telah dikelola oleh Kelompok Sadar Wisata (Pokdarwis) Desa Kotabatu. Pokdarwis Kotabatu saat ini sangat mengharapkan kontribusi nyata baik dari pemerintah kabupaten, provinsi, hingga pusat. Beberapa permasalahan klasik di antaranya terkait dengan penyediaan fasilitas infrastuktur jalan yang memadai, promosi wisata yang berkelanjutan, optimalisasi ekowisata sebagai wisata unggulan di Desa Kotabatu (Lampung Post, 17/2).

Mengacu pada permasalahan di atas, Tim Pelaksana Pengabdian Unggulan Unila kali ini mencoba untuk melakukan pemetaan potensi (eksplorasi) desa berbasis asset based community development di Desa Kotabatu, Kec. Pubian, Kab. Lampung Tengah. Aktivitas ini dilakukan sebagai perwujudan peran dan tanggung jawab perguruan tinggi menyebarluaskan hasil penelitian/kajian kepada masyarakat. Secara spesifik, hasil dari pemetaan (eskplorasi) potensi desa tersebut diharapkan dapat dijadikan sebagai pertimbangan dalam pengembangan kawasan perdesaan di Desa Kotabatu dengan memanfaatkan sumber daya alam dan sumber daya manusia setempat, serta mendatangkan pendapatan bagi masyarakat. Pelaksanaan pengabdian ini dilakukan dalam kurun waktu Mei s.d. September 2020. Untuk tahapan berikutnya, hasil kerja sama dan kemitraan yang sudah terjalin dengan Desa Kotabatu ditindaklanjuti dengan program KKN Tematik yang diselenggarakan oleh Universitas Lampung.

\section{Pendekatan Pelaksanaan Program}

Proses pemetaan dan pendampingan dalam kegiatan pengabdian ini mengadopsi model peningkatan kapasitas yang dikembangkan oleh Kretzmann \& McKnight (1996) yang memfokuskan pada peta aset masyarakat (community assets map) dan peta kebutuhan masyarakat (community needs map). Untuk itu, metode yang digunakan dalam kegiatan pengabdian kepada masyarakat ini mencakup beberapa tahapan, yakni sebagai berikut.

1. Tahapan Pendekatan

Pada tahap ini akan dilakukan proses konsolidasi dengan para pemangku kepentingan, baik tingkat desa, tingkat kecamatan, maupun tingkat kabupaten. Pada tahapan ini akan dipotret segala permasalahan mitra yang terkait dengan upaya pengembangan masyarakat berbasiskan aset.

2. Tahapan Pekerjaan

Pada tahapan ini, proses awal yang dilakukan ialah identifikasi faktor kekuatan dan kelemahan dalam upaya menemu-kenali potensi desa berbasiskan asset based community development. Berdasarkan proses identifikasi tersebut, diperoleh langkah strategis yang dapat digunakan dalam pertimbangan pengembangan kawasan perdesaan di Desa Kotabatu dengan memanfaatkan sumber daya alam dan sumber daya manusia setempat.

3. Tahapan Tindak Lanjut Program

Tahapan ini dilakukan agar terdapat keberlanjutan program dari pelaksanaan kegiatan pengabdian yang dilakukan. Pada aspek ini, tim PkM akan merekomendasikan kepada pemerintah daerah/pusat dan jaringan kelompok masyarakat lainnya tentang potensi Desa Ekowisata di Desa Kotabatu dengan mengoptimalisasikan 
peran Kelompok Hutan Memasyarakatan (HKm) dan Kelompok Sadar Wisata (Pokdarwis) yang ada.

\section{Pelaksanaan Program}

Kegiatan pengabdian ini dilaksanakan dalam empat rangkaian kegiatan, yakni persiapan pelaksanaan, pelatihan dan pendampingan, evaluasi, serta pelaporan. Persiapan pelaksanaan kegiatan pengabdian ini dilakukan selama dua bulan (April-Mei 2020). Adapun beberapa hal yang dipersiapkan ialah koordinasi di antara tim pelaksana $\mathrm{PkM}$ dan koordinasi dengan pihak pamong Desa Kotabatu. Selain itu, koordinasi melalui jejaring media massa (Lampung Post) yang merilis artikel tentang potensi alam Desa Kotabatu juga telah dilakukan oleh Tim PkM. Lebih lanjut, koordinasi dengan pihak Dinas Pertanian Tanaman Pangan dan Hortikultura serta UPTD Pertanian Kec. Pubian juga dilakukan agar pelaksanaan $\mathrm{PkM}$ menjadi lebih besinergi dan terintegrasi.

Tahapan pelaksanaan PkM dilakukan pada Sabtu, 18 Juli 2020 dan bertempat di Kantor Desa Kotabatu. Serangkaian aktivitas yang dilakukan meliputi pelatihan, pendampingan, dan proses evaluasi (pretest dan posttest). Pertemuan dilakukan dengan memerhatikan Protokol Kesehatan Pencegahan COVID-19. Dalam hal ini, para aparatur dan masyarakat desa cukup tanggap dalam mencegah penularan COVID-19 di Desa Kotabatu. Para peserta pelatihan menerapkan jaga jarak dan menggunakan masker selama dilakukannya pertemuan dengan tim PkM. Adapun lingkup materi yang disampaikan dalam pelatihan dan pendampingan mencakup beberapa hal berikut.

- Penjelasan mengenai community development pendekatan berbasis asset based community development dan tahapan implementasinya bagi masyarakat di Desa Kotabatu guna menemu-kenali potensi desa (prukades).

- Diskusi kelompok untuk mengenali berbagai potensi desa. Hal ini sebagai bagian dari pemetaan potensi desa dalam upaya pengembangan dan pembangunan desa. Pemetaan potensi desa yang dimaksud menggunakan ide (gagasan) sederhana untuk memanfaatkan potensi dan aset desa melalui langkah “3 D” (Dipetakan, Direncanakan, Dikelola) berskala kerja sama antarlembaga atau organisasi masyarakat.

- Pada tahap akhir, dilakukan evaluasi yang berfokus pada cara mengoptimalkan keterlibatan komunitas lokal dalam upaya pengembangan kesejahteraan masyarakat desa.

Pada sesi penyampaian materi Tim $\mathrm{PkM}$ fokus pada memfasilitasi para peserta dengan menjelaskan implementasi/pendekatan asset based community development (ABCD) sebagai 'alat' untuk dilakukannya pemetaan potensi desa. Selain itu, penjelasan mengenai Analisis 7 Bentang (A7B) juga dilakukan sebagai tahapan pekerjaan guna menemu-kenali potensi Desa Kotabatu. Setelah secara konseptual diperkenalkan metode ABCD kepada para peserta, tahapan berikutnya dilakukan diskusi kelompok yang terbagi menjadi tiga grup. Tim PkM mengarahkan kepada tiga grup ini untuk mendiskusikan perihal beragam potensi yang dimiliki oleh Desa Kotabatu dengan memperhatikan komponen aset desa yang telah dijabarkan sebelumnya. Sesi diskusi dilakukan selama 30 menit dan untuk berikutnya tiap kelompok dimintakan untuk melakukan presentasi dari hasil pemetaan yang telah dilakukan. 
Pada sesi FGD dengan para peserta pelatihan diperoleh informasi bahwa di Desa Kotabatu belum pernah dilakukan pernah dilakukan pemetaan potensi utamanya dengan menggunakan pendekatan asset based community development (ABCD). Untuk itu, kehadiran Tim PkM Unila membawa pemahaman baru kepada para peserta yang didominasi oleh para aparatur desa setempat. Namun, Desa Kotabatu telah memiliki 'modal sosial' yang cukup baik guna memulai mengoptimalkan potensi desa yang mereka miliki. Harmonisasi sosial telah terjalin dengan baik antara para apatur desa dan kelompok masyarakat. Hal ini terlihat pada keterlibatan seluruh elemen masyarakat Kotabatu dalam membangun desa mereka.

Pada sesi presentasi, terlihat gambaran yang kurang lebih hampir mirip di antara tiga kelompok dalam menemu-kenali potensi Desa Kotabatu. Potensi tersebut dapat diklasifikasikan menjadi (1) potensi sumber daya alam, (2) potensi hasil bumi, dan (3) potensi pariwisata.

Potensi sumber daya alam di Desa Kotabatu terlihat dari keberadaan hutan lindung di kawasan Register 22 Way Waya. Ditunjang oleh aliran sungai deras Way Pubian menjadikan area desa ini sebagai lahan yang subur guna ditanami beragam tanaman hortikultura. Selain itu, aliran sungai yang bersumber dari Bukit Barisan Selatan kerap dimanfaatkan oleh sebagian besar masyarakat Desa Kotabatu. Lebih lanjut, aliran sungai tersebut juga berkontribusi pada potensi sumber daya pariwisata di desa ini, setidaknya terdapat tiga potensi wisata yang dapat dikembangkan: (1) Air Terjun Curup Lestari, (2) Wisata Air Batutalang, (3) Tebing Kotabatu untuk olahraga Climbing.
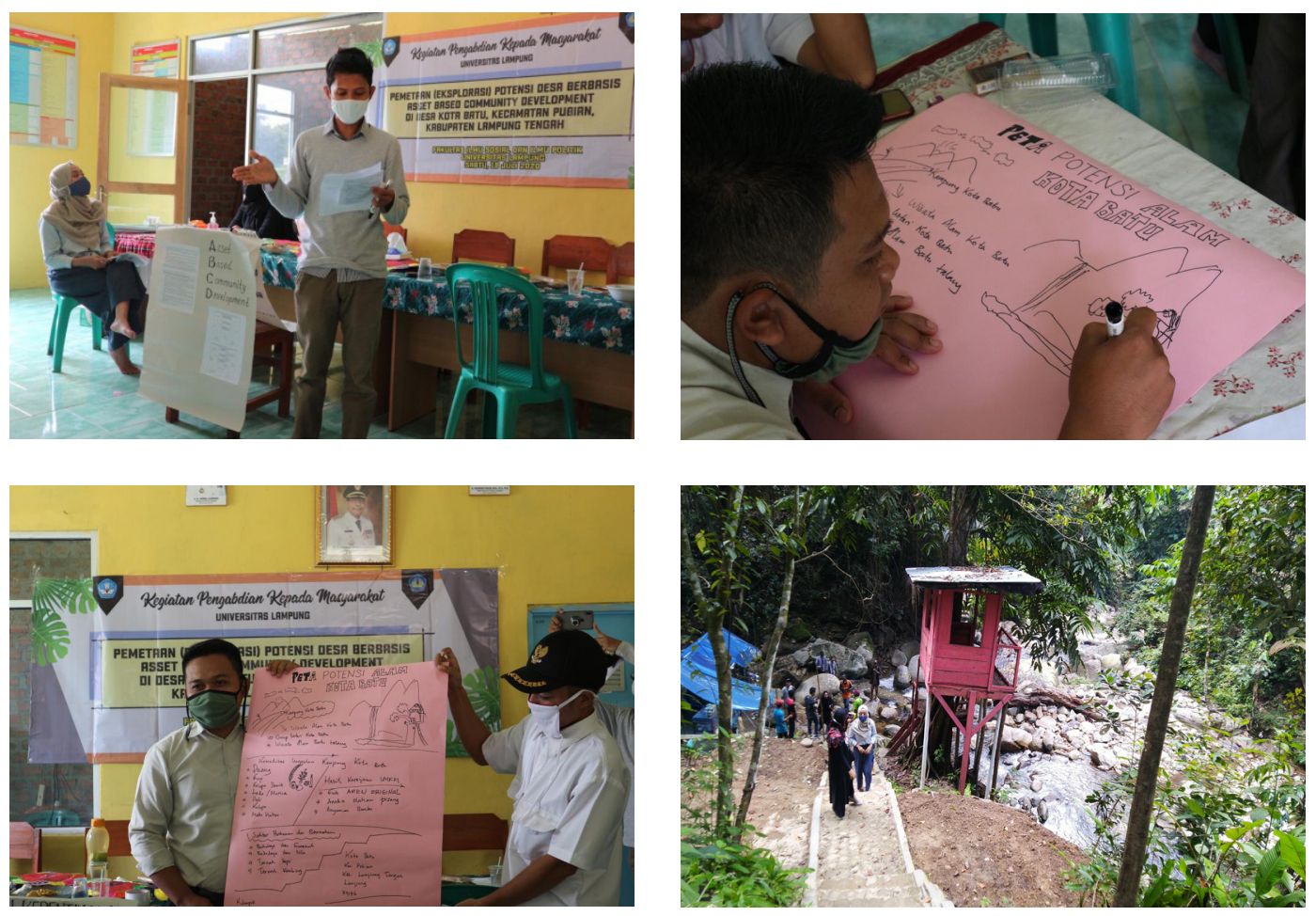

Gambar 2. Aktivitas PkM mencakup pelatihan, pendampingan dan pemetaan potensi Desa Kotabatu 
Tabel 2. Hasil Pemetaan Potensi Desa Mengacu pada Hasil Diskusi Kelompok (3 Group)

\begin{tabular}{|c|c|c|}
\hline $\begin{array}{c}\text { Group } 1 \\
\text { (Kelompok Susususasis) }\end{array}$ & $\begin{array}{c}\text { Group } 2 \\
\text { (Kelompok Suka-Suka) }\end{array}$ & $\begin{array}{c}\text { Group } 3 \\
\text { (Kelompok Sami Jaya Sity) }\end{array}$ \\
\hline 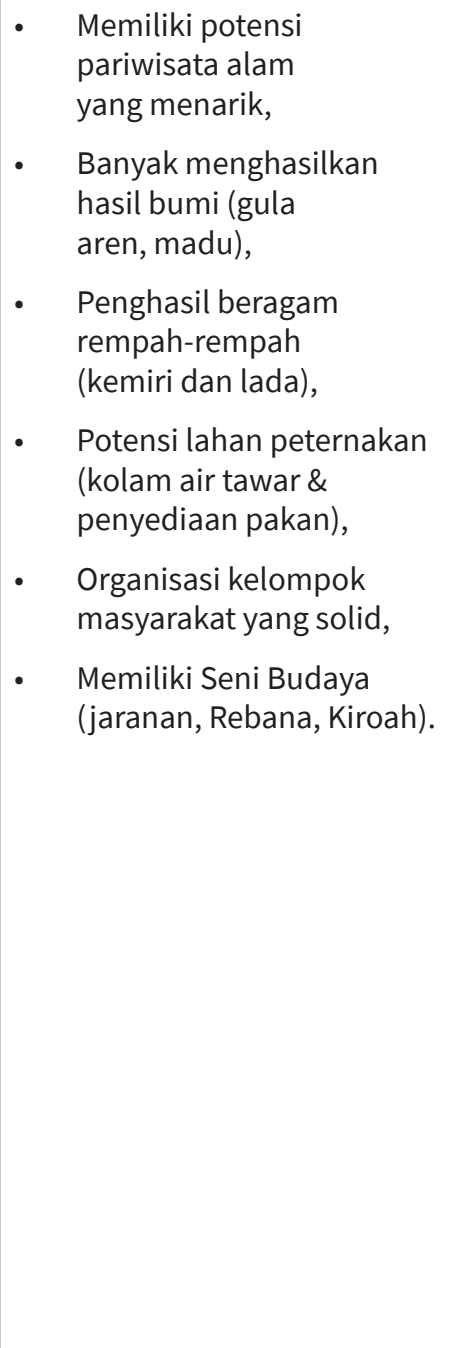 & $\begin{array}{l}\text { Potensi yang dapat } \\
\text { dikembangkan di } \\
\text { antaranya budi daya Ikan } \\
\text { Gurami. Ini potensi yang } \\
\text { sangat besar mengingat } \\
\text { Desa Kotabatu memiliki } \\
\text { aliran sungai yang jernih, } \\
\text { Saluran irigasi yang } \\
\text { telah tersedia dapat } \\
\text { dimanfaatkan untuk } \\
\text { pengembangan } \\
\text { budidaya ikan lainnya, } \\
\text { Selain itu, peternakan } \\
\text { sapi dan kambing hingga } \\
\text { kroto juga dapat dijadikan } \\
\text { alternatif pengembangan } \\
\text { usaha di Desa Kotabatu, } \\
\text { Untuk jenis hasil bumi } \\
\text { di antaranya: gula aren, } \\
\text { kolang-kaling, madu hutan, } \\
\text { kopi, kemiri, pinang, duren, } \\
\text { porang, hingga kelapa, } \\
\text { Jenis usaha lain yang } \\
\text { dapat dikembangkan } \\
\text { yakni kerajinan bambu } \\
\text { dan rotan yang sumber } \\
\text { bahan bakunya dapat } \\
\text { diperoleh dari hutan } \\
\text { disekitaran Desa Kotabatu. }\end{array}$ & $\begin{array}{l}\text { Potensi alam di Desa } \\
\text { Kotabatu yakni Air } \\
\text { Terjun Curug Lestari } \\
\text { yang sudah dikelola } \\
\text { oleh Pokdarwis dan } \\
\text { Batu Talang berada } \\
\text { di Desa Kotabatu } \\
\text { yang ada di bagian } \\
\text { selatan desa, } \\
\text { Desa Kotabatu berada } \\
\text { di lembah bukit barisan } \\
\text { Kawasan Register } 22 \\
\text { Way Waya memiliki } \\
\text { potensi wisata alam } \\
\text { yang menarik, } \\
\text { Komoditas unggulan } \\
\text { yang dihasilkan } \\
\text { oleh Desa Kotabatu } \\
\text { terdiri dari pisang, } \\
\text { kopi, kelapa sawit, } \\
\text { lada, padi, kelapa, } \\
\text { hingga madu hutan, } \\
\text { Hasil kerajinan UMKM } \\
\text { mencakup gula aren, } \\
\text { aneka olahan pisang, } \\
\text { dan anyaman bambu, } \\
\text { Untuk sektor perikanan } \\
\text { dan peternakan, desa } \\
\text { Kotabatu fokus pada } \\
\text { budi daya ikan Gurame, } \\
\text { ikan Nila, ternak } \\
\text { sapi dan kambing. }\end{array}$ \\
\hline
\end{tabular}

Sumber: Olahan Tim PkM

Adapun untuk jenis hasil bumi yang dihasilkan oleh Desa Kotabatu di antaranya adalah gula aren, kolang-kaling, madu hutan, kopi, kemiri, pinang, duren, porang, hingga kelapa. Untuk sektor perikanan dan peternakan, masyarakat di Desa Kotabatu fokus pada budi daya ikan gurami, ikan nila, ternak sapi dan kambing. Selain itu, variasi usaha lain yang dapat dikembangkan ialah kerajinan bambu dan rotan yang sumber bahan bakunya dapat diperoleh dari hutan di sekitaran Desa Kotabatu.

Pendekatan pengembangan masyarakat berbasis asset based community development (ABCD) secara konsep berfokus pada aset yang dimiliki masyarakat sebagai basis utama pengembangan program. Untuk itu, Tim PkM juga melakukan identifikasi peta aset masyarakat (community assets map) dan peta kebutuhan masyarakat (community needs map) di Desa Kotabatu. Secara umum, peta aset masyarakat di Desa Kotabatu cukup menunjang untuk mendukung program kemandirian desa. Hal ini terlihat dari dukungan 


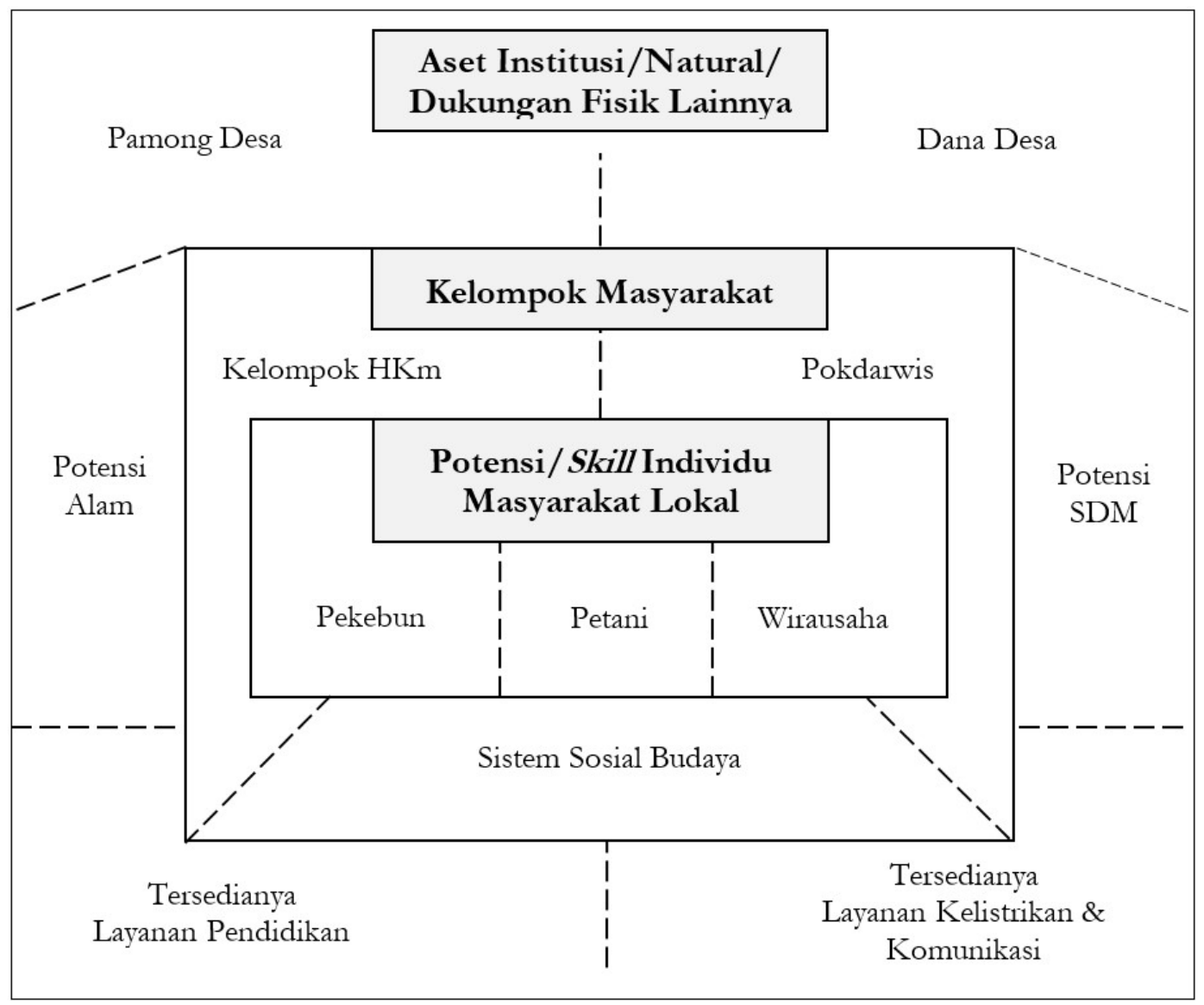

Gambar 3. Peta Aset Masyarakat (Community Assets Map) di Desa Kotabatu

aset institusi dan potensi yang dimiliki masyarakat lokal (sebagaimana yang tersaji pada Gambar 3). Namun, perkembangan Desa Kotabatu juga tidak terlepas dari beragam masalah yang kerap menjadi penghambat dalam upaya pembangunan desa. Lingkup permasalahan yang dihadapi Desa Kotabatu mencakupi permasalahan institusional, sosial, komunal, dan personal (lihat Gambar 4).

Pada pelaksanaan PkM ini, Tim Pengabdi juga menggali beragam 'isu' permasalahan yang dihadapi oleh masyarakat di Desa Kotabatu. Beberapa kendala yang dihadapi baik oleh aparatur desa maupun masyarakat lokal di Kotabatu di antaranya adalah sebagai berikut.

- Isu Administratif Pengembangan Potensi Pariwisata. Keberadaan Curup Lestari (kebanggaan masyarakat Desa Kotabatu) berada di areal hutan lindung. Untuk itu, penggunaan dana desa untuk membangun sarana dan prasarana area wisata tersebut terkendala oleh aturan yang menerangkan bahwa dana desa tidak dapat digunakan pada aeral hutan lindung tanpa ada izin dari Kementerian Kehutanan. Hal ini menjadi polemik tersendiri di Desa Kotabatu. Sebagian masyarakat mengkritisi perihal tidak dibangunnya sarana yang memadai (semisal membangun akses jalan yang layak) menuju lokasi wisata air terjun.

- Isu Ekologi \& Kebencanaan. Keberadaan Desa Kotabatu yang berada di lembah 


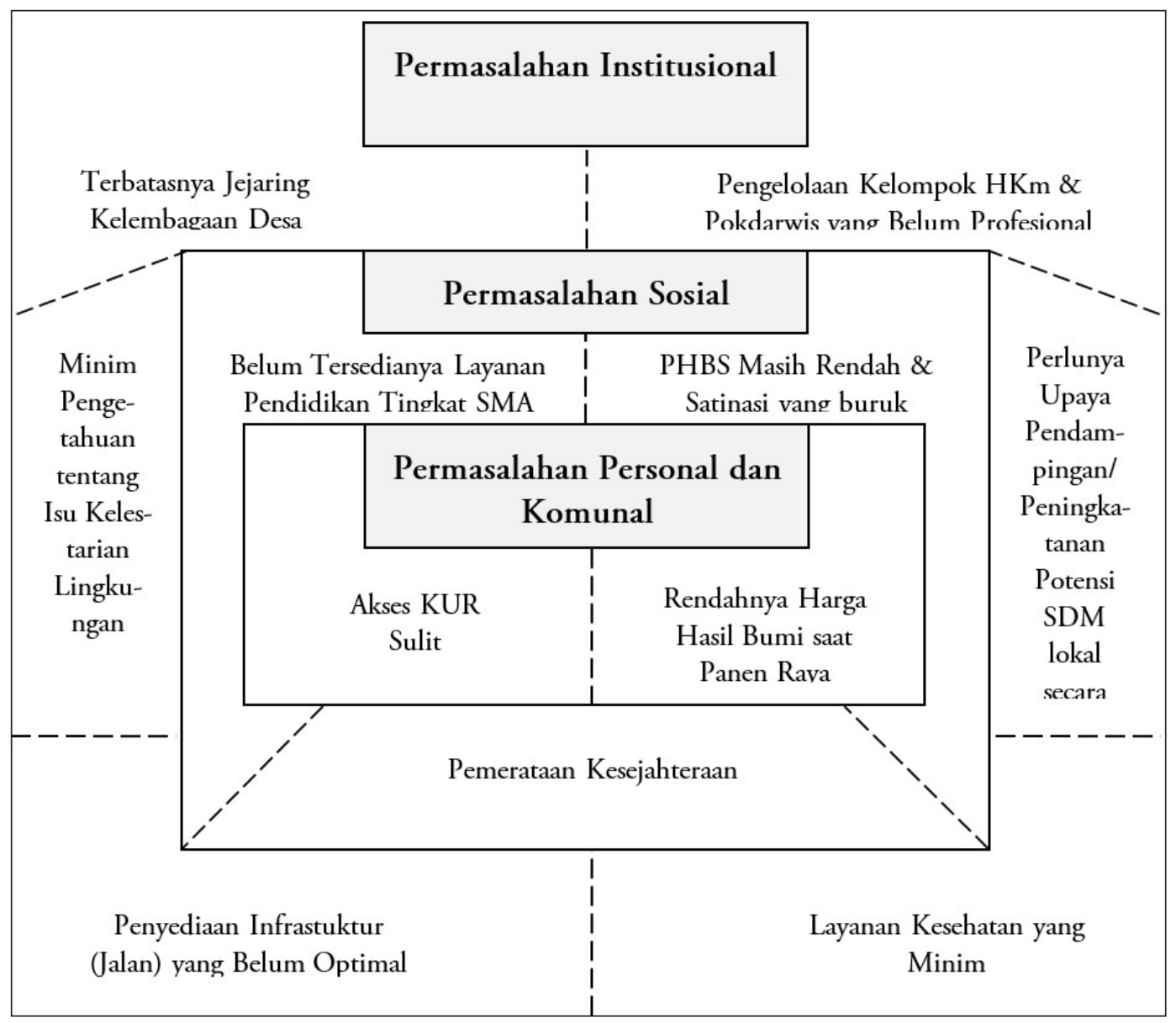

Gambar 4. Peta Kebutuhan Masyarakat (Community Needs Map) di Desa Kotabatu

dari salah satu Bukit Barisan Selatan tidak terlepas dari ancaman potensi bencana alam, misalnya banjir bandang. Bencana alam banjir bandang pernah melanda Desa Kotabatu pada tahun 1992, para warga menceritakan sebanyak 18 rumah yang hancur akibat dari bencana tersebut, utamanya rumah yang berada di pinggiran area sungai. Warga menuturkan bila musibah di tahun 1992 tersebut murni dari bencana alam yang diakibatkan longsoran pohon dan tanah dari bagian hulu lalu menerjang ke bagian hilir. Selain itu, hutan lindung dikawasan Register 22 Way Waya yang berada dipinggiran Desa Kotabatu juga tak luput dari tindak kriminal oknum tertentu yang melakukan penebangan pohon untuk diambil kayunya, terutama jenis Sono Keling. Dalam beberapa tahun terakhir, kasus perambahan hutan sudah tidak lagi terjadi karena pengelola hutan lindung (melalui polisi hutan) kerap melakukan operasi menyisir masuk hutan dalam rangka meminimalisasi terjadinya kasus tersebut agar tidak terulang.

- Isu Infrastuktur. Jalan provinsi yang menghubungkan antara Kec. Gunung Sugih, Kec. Anak Tuha, Kec. Padang Ratu, dan Kec. Pubian banyak dilalui oleh Truk Fuso yang membawa material bahan baku pembuatan keramik lantai, orang lokal menyebutnya 'padas'. Padas ini dibawa dengan menggunakan truk fuso ke pabrik 
keramik yang berada di wilayah tersebut. Muatan truk yang sangat banyak tersebut pada akhirnya berdampak pada rusaknya jalan penghubung antarkecamatan di Lampung Tengah.

- Isu Kamtibmas. Sejatinya, situasi kamtibmas di Desa Kotabatu dapat dikategorikan 'aman', hanya saja ada semacam 'pelabelan' yang kurang baik untuk Pubian, yakni wilayah dengan tingkat kriminalitas yang tinggi. Hal ini sebagaimana yang diungkapkan oleh Pak Sakino (selaku Kepala Desa Kotabatu) yang menyatakan:

"Desa Kotabatu merupakan desa paling ujung, akses jalannya hanya satu ini dan tertutup oleh bukit barisan. Oleh karenanya, ini keuntungan tersendiri bagi desa kami. Dapat dikatakan, hanya penduduk lokal ini saja yang kemudian beraktivitas di sekitaran desa ini dan kami saling mengawasi satu sama lain. Banyak orang yang bilang kalau wilayah Kec. Pubian yang rawan begal, ya sebenarnya itu hanya di beberapa kampung saja, utamanya Kec. Pubian bagian utara yang berbatasan dengan Kotabumi (Lampung Utara). Pada akhirnya seluruh wilayah Pubian kena imbas dari pelabelan itu".

Pada awal dilaksanakannya PkM ini, Tim Pelaksana cukup tertantang untuk menyambangi wilayah Pubian karena banyak beredar informasi seputar 'kerawanan' wilayah tersebut. Akses yang dilalui untuk menuju Desa Kotabatu diambil rute melalui Gunung Sugih, lalu melewati Kec. Anak Tuha, kemudian Kec. Padang Ratu, barulah masuk ke Kec. Pubian. Tiga kecamatan di Lampung Tengah ini memang perlu mendapat perhatian lebih dari stakeholder terkait, khususnya aparat pemerintahan dan keamanan guna 'menghilangkan' label 'wilayah rawan tindak kejahatan' di Kabupaten Lampung Tengah.

\section{Refleksi Capaian Program}

Program pengabdian kepada masyarakat ini telah berhasil meningkatkan pengetahuan dan pengalaman masyarakat lokal dalam memetakan potensi desa berbasiskan asset based community development di Desa Kotabatu. Mengacu pada hasil evaluasi, kegiatan pengabdian ini telah berhasil meningkatkan pengetahuan dan pemahaman para peserta sebesar 6,67\%. Perlu diketahui, untuk tahapan evaluasi dari kegiatan pengabdian ini mencakup pretest dan posttest. Untuk pretest diselenggarakan sebelum peserta mendapatkan materi pelatihan dan pendampingan, sedangkan posttest diselenggarakan di akhir kegiatan. Ada lima pokok item yang menjadi bahasan di tahapan evaluasi ini, yaitu (1) urgensi pemetaan potensi desa, (2) konsep pendekatan asset based community development (ABCD), (3) lingkup pengembangan 'pariwisata berkelanjutan', (4) manfaat yang diperoleh dari pengembangan sektor pariwisata, dan (5) para pelaku (pemangku kepentingan) pada pengembangan sektor pariwisata.

Pada tataran praktis, program PkM ini telah berhasil memvisualisasikan pemetaan aset dan kebutuhan masyarakat Desa Kotabatu yang menyajikan potensi atau keunggulan yang dimiliki oleh masyarakat lokal. Mengacu pada hasil pemetaan tersebut, masyarakat Desa Kotabatu menyadari bahwa mereka memiliki segenap kekuatan dan kapasitas untuk berkembang. Hal ini sebagaimana yang diungkapkan oleh salah satu peserta pengabdian dalam sesi evaluasi akhir. Peserta tersebut menyadari perlunya dilakukan kolaborasi untuk mengoptimalkan potensi wisata yang ada di daerah mereka. Kolaborasi 
yang dimaksud ialah inisiatif kerja sama yang dapat dilakukan dengan Desa Linggapura yang persis bersebelahan dengan Desa Kotabatu. Jika di Kotabatu ada Curup Lestari, di Linggapura ada Curup Tujuh. Apabila kerja sama ini dilakukan dan dioptimalkan, misalnya dengan saling mendukung/mengampanyekan keberadaan objek wisata tersebut, mereka meyakini bahwa dengan mengoptimalkan potensi wisata yang ada akan mampu meningkatkan perekonomian masyarakat lokal. Lebih dari itu, aparatur desa juga menyadari pentingnya mengoptimalkan fungsi kelembagaan desa yang ada, misalnya dengan meningkatkan kemampuan pengelolaan manajerial BUMDes Desa Kotabatu hingga wacana pembentukan kelompok tanggap bencana, mengingat letak geografis Desa Kotabatu yang rawan terjadi bencana alam.

Terkait dengan pendekatan asset based community development (ABCD), Mathie dan Cunningham (2003) mengungkapkan bahwa pendekatan ABCD hanya sebagai titik awal, meyakini bahwa setiap masyarakat lokal memiliki kekuatan dan kapasitas untuk meningkat taraf hidupnya ke arah lebih baik. Dengan menemu-kenali seperangkat kekuatan tersebut, hal itu menjadi penggerak untuk dilakukannya sebuah tindakan guna mewujudkan keinginan-keinginan masyarakat yang telah dicanangkan. Dalam mewujudkan keinginan masyarakat Desa Kotabatu yang menaruh 'harapan' menjadi destinasi desa ekowisata, tercetuslah dari Kepala Desa mengenai keberlanjutan program serupa agar ada/dilakukan pendampingan yang lebih lama. Hal ini dirasa penting oleh mereka guna apa-apa yang telah dirancang, dilakukan dengan benar dan tepat. Merespons hal itu, tim pengabdi menggulirkan gagasan untuk pendampingan berikutnya dapat dikolaborasikan dengan program KKN Tematik Unila yang kerap dilakukan setiap tahun. Memang menurut pengakuan pamong desa, KKN Unila di desa mereka terakhir dilakukan pada tahun 2017 dan ini menjadi peluang baik dalam keberlanjutan pengembangan potensi Desa Kotabatu.

\section{Penutup}

Kegiatan pengabdian ini telah mengarah pada beberapa capaian tujuan, yaitu terbangunnya komitmen di antara aparatur desa untuk memfokuskan pengembangan desa pada tiga potensi yang dimiliki oleh Desa Kotabatu, di antaranya, yakni (1) optimalisasi potensi SDA, (2) potensi hasil bumi, dan (3) potensi pariwisata. Terkait dengan itu, di Desa Kotabatu memang belum pernah dilakukan pemetaan potensi desa utamanya dengan menggunakan pendekatan asset based community development (ABCD). Untuk itu, kehadiran Tim PkM Unila membawa pemahaman baru kepada para peserta yang didominasi oleh para aparatur desa setempat. Dengan terpetakannya community assets map (peta aset masyarakat) dan community needs map (peta kebutuhan masyarakat) di Desa Kotabatu, tergalilah beragam potensi atau keunggulan yang dimiliki oleh masyarakat lokal. Besar harapan mereka mewujudkan Desa Kotabatu destinasi desa ekowisata. Para apartur desa menyadari bahwa keunggulan daya tarik pariwisata yang dimiliki perlu terus dipromosikan. Upaya kolaborasi dan kerja sama dengan berbagai pihak menjadi tindakan konkret awal yang harus dilakukan sebagai langkah pengembangan potensi desa. Adapun luaran rekomendasi yang diajukan mengacu pada hasil pelaksanaan PkM, yakni (1) diperlukan pendampingan yang berkelanjutan dengan melibatkan stakeholders terkait dengan upaya pengembangan desa (baik perguruan tinggi, pemerintah kabupaten, 
maupun pendamping desa), dan (2) dalam upaya pengembangan potensi pariwisata perlu mengoptimalkan keterlibatan dan peran beberapa pihak, baik masyarakat desa, kalangan pemerintah, institusi perguruan tinggi, media massa, maupun pelibatan dunia usaha/swasta.

\section{Daftar Pustaka}

Datin Kemendesa. (2020). Daftar BUMDes di Provinsi Lampung. Diunduh dari http:// datin.kemendesa.go.id/simpora/rep_bumdessmry.php

Kemendesa PDTT. (2020). Indeks Desa Membangun Kab. Lampung Tengah. Diunduh dari https://idm.kemendesa.go.id/idm_data

Kemendikbud.go.id. (2020). Mendikbud: Proyek Membangun Desa Jadi Sarana Penguatan Karakter Mahasiswa. Diunduh dari: https://www.kemdikbud.go.id/ main/blog/2020/01/ mendikbud-proyek-membangun-desa-jadi-sarana-penguatankarakter-mahasiswa

Kompas.com. (2020). Mendes Dorong Dana Desa untuk Pembiayaan Proyek Desa Kemdikbud. Diunduh dari: https://edukasi.kompas.com/read/2020/01/31/16500011/mendesdorong-dana-desa-untuk-pembiayaan-proyek-desa-kemendikbud?page=all

Kretzmann, J. dan McKnight, J. P. (1996). Assets-Based Community Development. National Civic Review, 85(4), 23-29.

Lampung Post. (2020). Curup Tiga Tingkat nan Memesona di Kotabatu. Bandar Lampung: Harian Umum Lampung Post.

Maps Google. (2020). Desa Kotabatu, Kec. Pubian, Kab. Lampung Tengah. Diunduh dari https://maps.google.co.id/

Mathie, A. dan Cunningham, G. (2003). From Clients to Citizens: Asset-Based Community Development as a Strategy for Community-Driven Development. Development in Practice, 13(5), 474-486.

Prukades Kemendesa. (2020). Daftar Prukades di Provinsi Lampung. Diunduh dari http://prukades.kemendesa.go.id/lpage/

Yulianto, Y., Diana, S., Fahmi, T., Hidayati, D. A., \& Inayah, A. (2021). Pemetaan Potensi Desa-Prukades dan Pendampingan Peningkatan Kapasitas BUMDES di Pekon Sukabanjar, Lumbok Seminung, Lampung Barat. Sawala: Jurnal pengabdian Masyarakat Pembangunan Sosial, Desa dan Masyarakat, 2(1), 1-8.

Youtube.com. (2020). Hutan Kemasyarakatan Bukan Lagi Janji di Lampung Tengah. Diunduh dari https://www.youtube.com/watch?v=FMAJWXAjoo4 